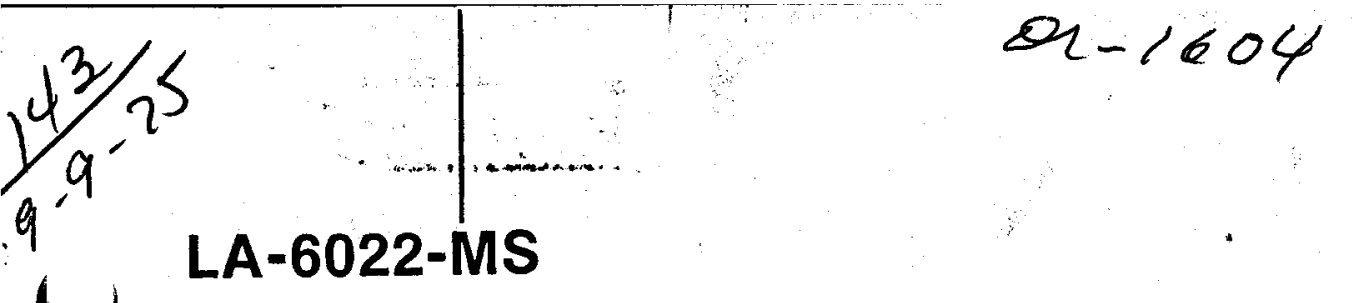

Informal Report by

\author{
James N. Albright
}

UC.13

Reporting Date: June 1975 Issued: July 1975

\title{
Temperature Measurements in the Precambrian Section of Geothermal Test Hole No. 2
}


In the interest of prompt distribution, this report was not edited by the Technical Information staff.

Printed in the United States of America. Available from National Technical Information Service U S Department of Commerce

$$
5285 \text { Port Royal Road }
$$

Price: Printed Copy $\$ 4.00$ Microfiche $\$ 2.25$ 


\section{DISCLAIMER}

This report was prepared as an account of work sponsored by an agency of the United States Government. Neither the United States Government nor any agency Thereof, nor any of their employees, makes any warranty, express or implied, or assumes any legal liability or responsibility for the accuracy, completeness, or usefulness of any information, apparatus, product, or process disclosed, or represents that its use would not infringe privately owned rights. Reference herein to any specific commercial product, process, or service by trade name, trademark, manufacturer, or otherwise does not necessarily constitute or imply its endorsement, recommendation, or favoring by the United States Government or any agency thereof. The views and opinions of authors expressed herein do not necessarily state or reflect those of the United States Government or any agency thereof. 


\section{DISCLAIMER}

Portions of this document may be illegible in electronic image products. Images are produced from the best available original document. 
TEMPERATURE MEASUREMENTS IN THE PRECAMBRIAN SECTION

OF GEOTHERMAL TEST HOLE NO. 2

by

James N. Albright

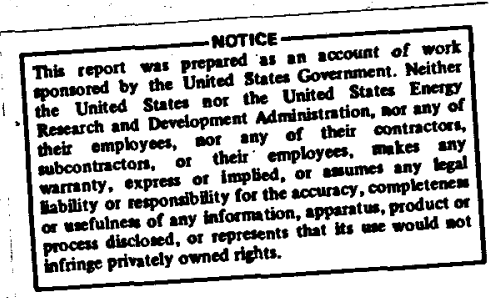

ABSTRACT

Temperature measurements have been made throughout most of the Precambrian section of Geothermal Test Hole No. $2(G T-2)$, the second deep exploratory test hole in the Los Alamos Scientific Laboratory's Dry Hot Rock Geothermal Energy Project. Successful bottomhole temperature measurements were made at nine successive depths during interruptions in drilling. A thermistor probe was used to measure temperature under conditions in which the bottom $10 \mathrm{~m}$ of the borehole was filled with either air, water, mud, or water-saturated silt. Several techniques were developed to insure. that the thermistor sonde was positioned directly on bottom and isolated from the convecting borehole fluids. These techniques proved successful. Equilibrium rock temperatures calculated from relaxation data using a new method show geothermal gradients of from 50 to $60^{\circ} \mathrm{C} / \mathrm{km}$ in the intervals measured, the gradient generally increasing with depth. The equilibrium rock temperature is $195.8^{\circ} \mathrm{C}$ at a depth of $2900 \mathrm{~m}(28 \mathrm{~m}$ above the present bottom of the borehole) based on $30 \mathrm{~h}$ of continuous bottomhole temperature measurements. The extrapolated equilibrium rock temperature at the GT-2 terminal depth of $2928 \mathrm{~m}$ is $197^{\circ} \mathrm{C}$.

\section{INTRODUCTION}

A 2928-m-deep (9607-ft) 244-mm-diam (9-5/8-in.) borehole recently has been drilled as part of the Los Alamos Scientific Laboratory's Dry Hot Rock Geothermal Energy Project. This borehole, designated Geothermal Test Hole No. 2, or simply GT-2, is located on the western flank of the Valles Caldera in north-central New Mexico. An effort was initiated to develop methods for measurement and data reduction which would allow determination of rock temperatures during economically acceptable interruptions in drilling operations. This goal has been realized.

Past attempts at inferring rock temperatures have been concentrated on the analysis of relaxation temperatures measured in a fluid-filled borehole sufficiently distant from the bottom so that end effects could be ignored and data could be reduced using cylindrical heat-flow theory. ${ }^{1-3}$ However in GT-2 the time necessary for temperature relaxation to approach theoretical behavior (neglecting convective disturbances) was prohibitively long for these methods to be of practical use during drilling.
Rapid determination of the equilibrium rock temperature is possible, however, if bottomhole measurements are used. Since the rock at the bottom of a borehole is the least disturbed by the drilling process, the temperature range observed there during relaxation is substantially greater than that observed elsewhere in the borehole. This gives the desirable result of reducing both the precision and amount of data needed for accurate equilibrium rocktemperature determinations. Furthermore, at the bottom of a borehole, temperature sensors easily can be isolated from the cooling effects of convecting borehole fluids.

White et al. ${ }^{4}$ Grisafi et al., ${ }^{5}$ and Summers ${ }^{6}$ approximate equilibrium rock temperatures by measuring the bottomhole temperature with a maximum-reading thermometer. However, the use of maximum-reading thermometers in high-temperature, low-permeability rocks--an environment not encountered by these investigators--is likely to introduce significant error. In the hot and essentialiy impermeabie basement rocks encountered in GT-2, the measured bottomhole 
temperatures increasingly diverge, with depth, from the equilibrium rock temperatures. This is because the cooling effect of the drilling process is more pronounced at higher rock temperatures, and cannot be as quickly reduced by fluid exchange between the borehole and the surrounding rocks as it can be in low-temperature permeable rocks.

This report summarizes a new method by which equilibrium rock temperatures are inferred with high precision from an analysis of the thermal recovery of the bottomhole temperature measured continuously during a time interval of less than $24 \mathrm{~h}$. The gradient in GT-2 is the first gradient to be so determined.

\section{BOREHOLE PREPARATION FOR TEMPERATURE MEASUREMENTS}

Considerable effort was expended in finding suitable ways to position a temperature sonde on successive bottoms of GT-2 and to isolate the sonde from the effect of convecting fluids. At depths in excess of $1.3 \mathrm{~km}(4265 \mathrm{ft})$, temperature measurements were made in a borehole in which the bottom $10 \mathrm{~m}$ (33 ft) was filled with either water, a viscous mud, or water-saturated silt. The remainder of the borehole was water filled. After cessation of drilling, drilling fluid circulation was maintained for a specified period of time, usually on the order of an hour, to insure that the borehole was as clear as possible of silt and larger rock fragments. With the drill string removed, bottomhole temperature measurements with a thermistor sonde could be taken if complete removal of silt was anticipated. If not, an open-ended dri11 string was set $2 \mathrm{~m}(6.6 \mathrm{ft})$ off bottom, a sonde then lowered through the drill string and a volume of high viscosity drilling mud pumped to bottom. Mud inhibited the settling of silt and allowed the probe to be positioned on bottom and easily retrieved. The use of viscous mud had the added advantage of damping convective instabilities arising from the high temperature gradient.

At depths greater than $2 \mathrm{~km}$, excessive silt and dehydration of the bentonitic mud necessitated adoption of a scheme in which the drill string, terminated in a phenolic adapter, was washed to bottom by fluid circulation supplied by the rig pump (Fig. 1). On cessation of pump circulation, the phenolic end was set on bottom and the temperature sonde lowered through the drill string and inserted into the

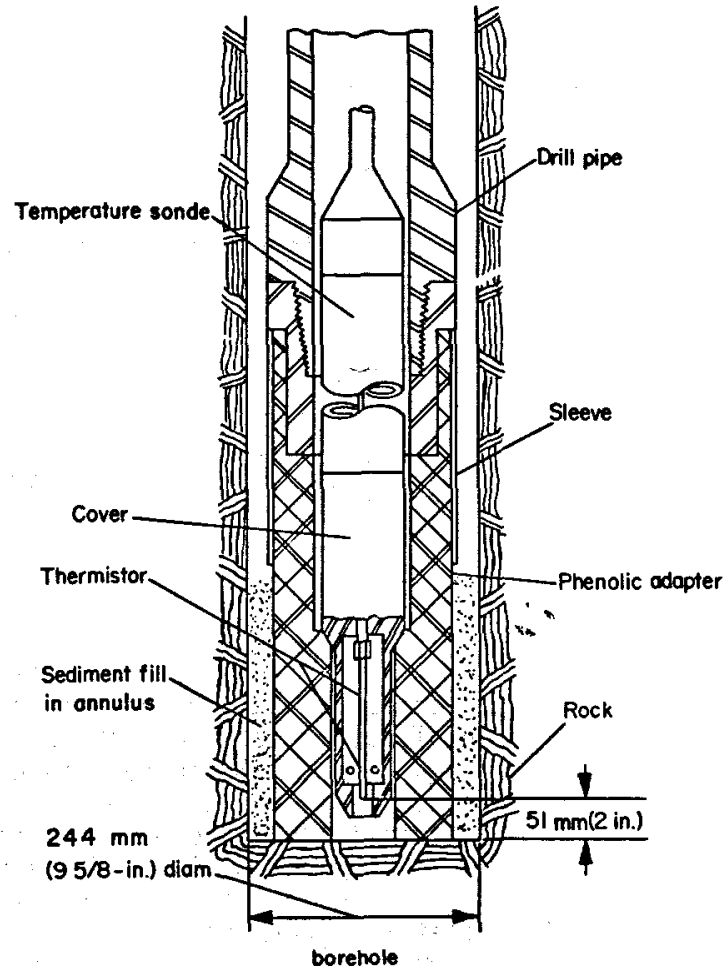

Fig. 1. Phenolic extension to the drill string used for bottomhole temperature measurements.

adapter. The eventual settling of silt between the drill pipe and borehole wall prevented all but pore fluid movement in this annulus. The adapter-sonde seal mating entrapped a small amount of water at the bottom of the borehole and essentially isolated the thermistor from the effects of convective water currents in and surrounding the drill pipe.

\section{DATA REDUCTION}

Assume for an arbitrary time interval, short in comparison with the time required for temperature relaxation to be complete, that the rate of temperature relaxation depends only on the difference between the bottomhole temperature and the equilibrium, or undisturbed, rock temperature. Allowing the constant in this proportionality to vary from interval to interval, and following the change in the proportionality with time, enables the determination of equilibrium rock temperature. It will be shown that relaxation temperatures observed at any depth in a borehole can be treated in the same manner to give equilibrium rock temperature. However, sufficient data can be collected in hours rather than months or years, if only bottomhole temperatures are measured. 


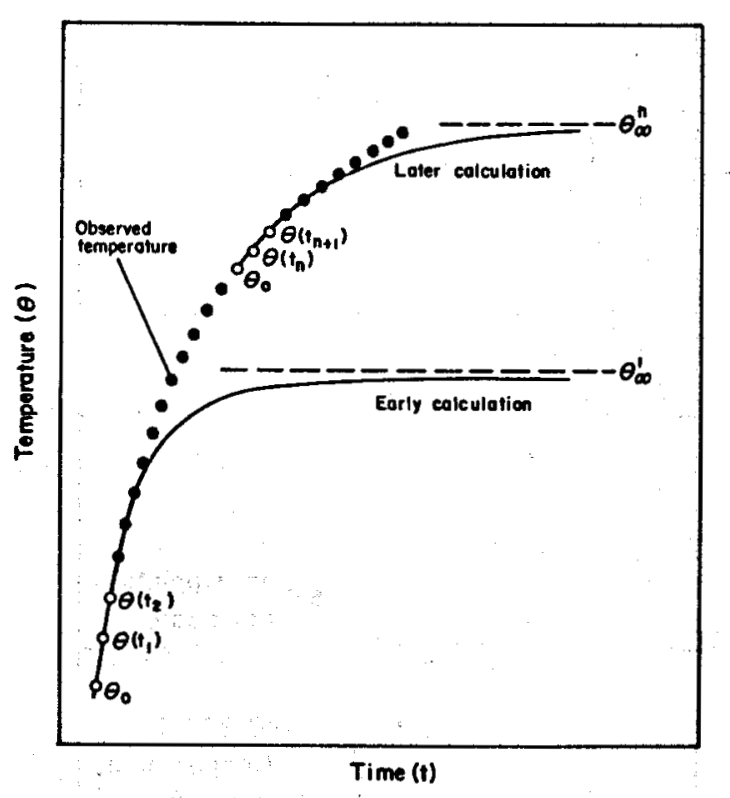

Fig. 2. Calculation of $c^{i} \theta_{\infty}^{i}$ interval parameters. Typically the range of $\theta_{\infty}^{l}$ is less than $12^{\circ} \mathrm{C}$.

Muskat, 7 in an analys is of oil-well production, makes the above assumption for pressure relaxation, but requires that the same proportionality hold throughout the entire period of relaxation. Following Muskat's theoretical development expressed in terms of temperature, we have for the ith time interval beginning at $t_{0}$ :

$\theta^{i}(t)-\theta_{\infty}^{i}=\left(\theta_{0}^{i}-\theta_{\infty}^{i}\right) \mathrm{e}^{-c^{i}\left(t-t_{0}^{i}\right)}$,

where $c^{i}$ is a constant for the ith interval, and $\theta_{0}^{i}$ $\theta^{i}(t)$, and $\theta_{\infty}^{i}$ are temperatures at times $t_{0}^{i}, t$, and $t_{\infty}$, respectively. Knowing the temperature at three specified times, two equations can be written and solved simultaneously for the unknown interval parameters $c^{i}$ and $\theta_{\infty}^{i}$ Repeating this process $n$ times, new choices are made of $t_{0}^{i}$ and new values for $c^{i}$ and $\theta_{\infty}^{i}$ are calculated. Figure 2 shows two such calculations, one at early time and another at later time. For temperature relaxation, a unique value of $\theta_{\infty}^{i}$ cannot be found which reproduces all of the observed temperature data if $c^{i}$ is held constant throughout the entire relaxation interval (Muskat's method). In our case, since $c^{i}$ varies during relaxation, only temperature behavior during intervals short in comparison to complete recovery can be modeled by any

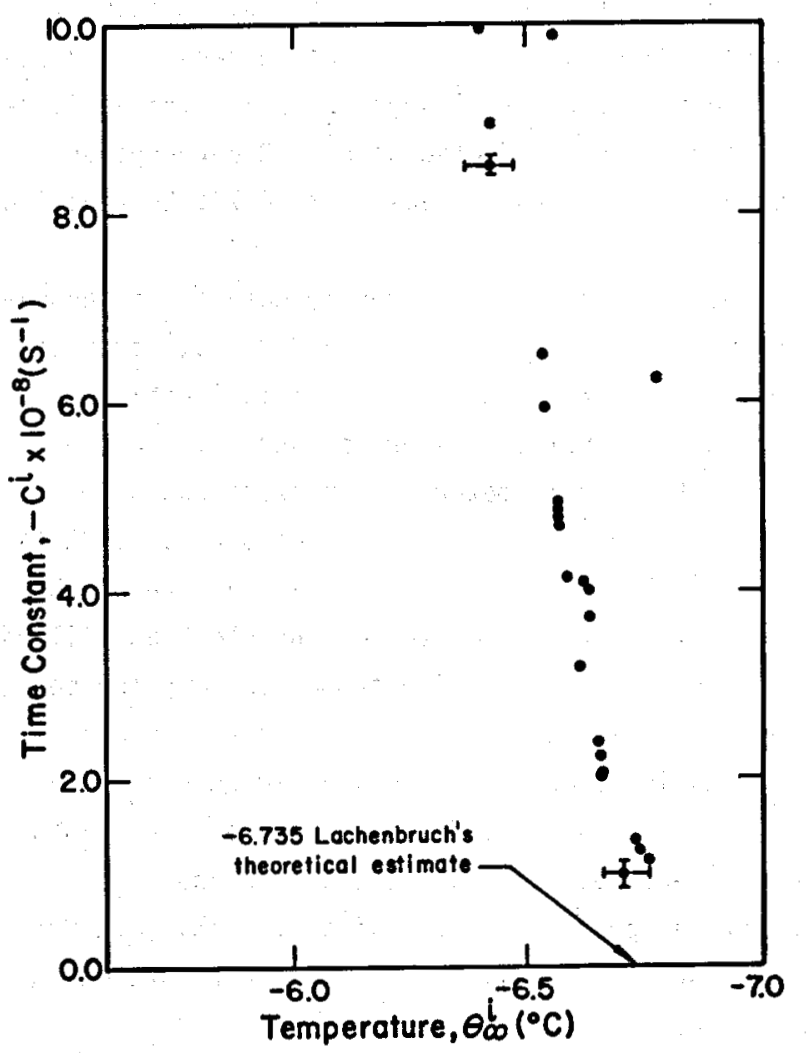

Fig. 3. Reduction of temperature recovery data ${ }^{7}$ for a depth of $181 \mathrm{~m}$ (595 ft) in the South Barrow Well No. 3 .

particular calculated $\theta_{\infty}^{i}$. With successive calculations of $\theta_{\infty}^{i}$, both the curve fit and the extrapolation to the undisturbed rock temperature improve.

The choice of the time interval, $t_{2}^{i}-t_{0}^{i}$, for successive calculations of $c^{i}$ and $\theta_{\infty}^{i}$ is made to maximize the range of $\theta_{\infty}^{i}$ available from the observed temperature data within limitations imposed by the precision of the temperature measurements. A plot of $c^{i}$ versus $\theta_{\infty}^{i}$ enables the determination of equilibrium rock temperature $\theta_{\infty}^{i}$ since, as $c^{i}+0, \theta_{\infty}^{i} \rightarrow \theta_{\infty}$. Regression analysis of the linear portion of each $c^{i} \theta_{\infty}^{i}$ curve is used to obtain the most likely value of $\theta_{\infty}$.

Theoretical and Experimental Verification of the LASL Method

That the dependence of $c^{i}$ on $\theta_{\infty}^{i}$ is not a transient phenomenon is demonstrated by the analysis of data reported by Lachenbruch and Brewer. 1 Figure 3 shows a $c^{i} \theta_{\infty}^{i}$ plot calculated from temperature measurements made at a depth of $181 \mathrm{~m}$ (595 ft) during a 
6-yr period after the drilling of a $610-\mathrm{m}$ (2000-ft) well near Barrow, Alaska.* As can be seen, $c^{i}$ closely approaches zero as $\theta_{\infty}^{i}$ approaches $\theta_{\infty}$. The equilibrium temperature predicted at $c^{i}=0$ corresponds closely to Lachenbruch's value of $-6.735^{\circ} \mathrm{C}$ predicted from theory. $\star \star$

Analysis of thermal recovery data for a laboratory model, reported by Cooper and Jones, ${ }^{2}$ provides experimental verification of the relationship between the interval parameters $c^{i}$ and $\theta_{\infty}^{i}$. In their experiment, a cubic meter of sandstone was allowed to come to equilibrium with room temperature. A 4cm-diam (1.5-in.), 0.6-m-deep (24-in.) borehole was then drilled into the center of the block and filled with a chilled slurry. The temperature in the borehole 8 diameters off bottom was measured intermittently during thermal recovery. Figure 4 shows a $c^{i} \theta_{\infty}^{i}$ plot for the recorded temperature data. Both the $c^{i} \theta_{\infty}^{i}$ extrapolation and the Cooper and Jones theoretical prediction approximate, within measurement error, the equilibrium rock temperature which in this case is known.

Equilbrium and Virgin Rock Temperatures

The term "equilibrium" rock temperature is here used in its usual context: the steady-state temperature which would exist when thermal relaxation was complete. However, the equilibrium rock temperature at a specified depth need not be equivalent to the temperature at that depth prior to drilling. The latter temperature is commonly called the virgin rock temperature. The difference arises from permanent changes in the physical and chemical properties of the surrounding rock, and from the presence of the borehole. Neither the magnitude nor the significance of this difference can be evaluated; however, it is presumed to be small.

\section{Errors in Temperature Measurement}

The accuracy of each temperature determination is estimated to be $\pm 0.2^{\circ} \mathrm{C}$. Precision in measurement is limited by the rate of change of thermistor resistance and by the minimum measureable resistance with temperature.

*Probable errors in Fig. 3 have been calculated assuming an $0.008^{\circ} \mathrm{C}$ precision-of-measurement over the entire range of observed temperature, rather than the $0.01^{\circ} \mathrm{C}$ estimated by Lachenbruch.

$\star *$ The application of a theoretical model presented by Lachenbruch and Brewer to the bottomhole temperature relaxation observed in GT-2 is discussed in Appendix A.

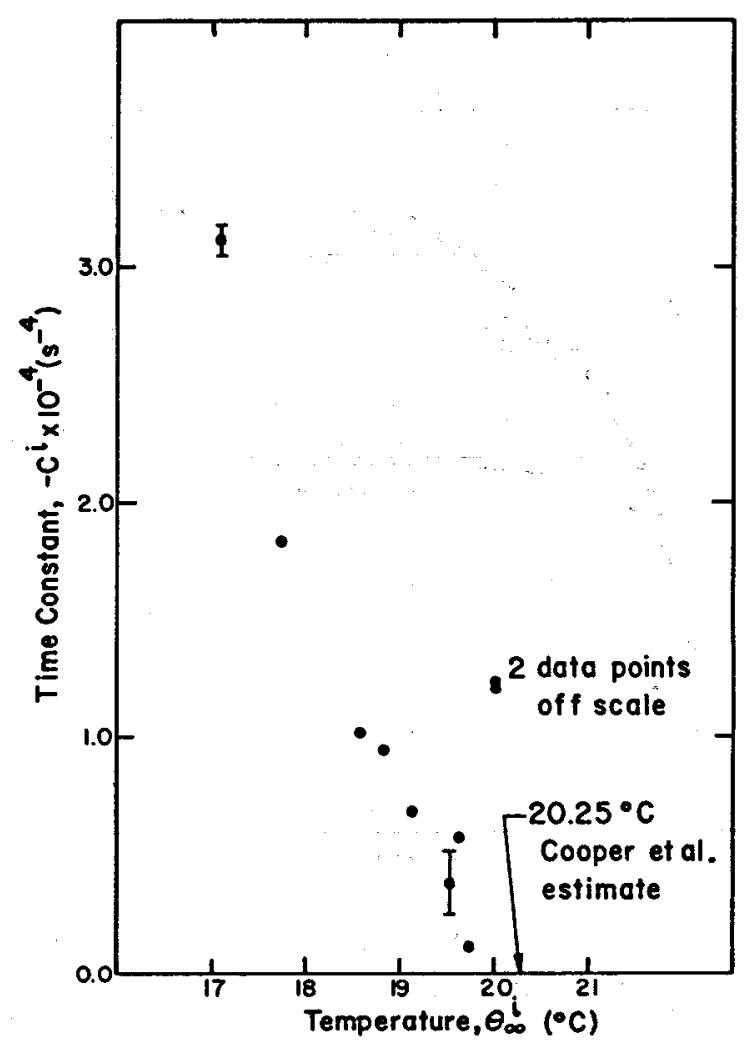

Fig. 4. Reduction of temperature recovery data ${ }^{2}$ for laboratory experimental model.

The precision of measurement is generally better than $0.01^{\circ} \mathrm{C}$ for temperatures less than $200^{\circ} \mathrm{C}$. Errors in $c^{i} \theta_{-\infty}^{i}$ Plots

Systematic errors have negligible effect on $c^{i}$ but substantially affect $\theta_{\infty}^{i}$. For instance, a $1 \%$ systematic measurement error in the thermistor resistance results in $0.3^{\circ} \mathrm{C}$ error in $\theta_{\infty}^{i}$. Random measurement errors cause uncertainties in both $c^{i}$ and $\theta_{\infty}^{i}$, skewed principally in the direction of higher $\theta_{\infty}^{i}$ and lower $c^{i}$. Both of these latter errors increase with decreasing $c^{i}$. Uncertainties at small $\mathrm{c}^{i}$ can be reduced by choice of a greater time interval in computing $c^{i}$ and $\theta_{\infty}^{i}$, but such a choice has the undesirable consequence of reducing the range of $\theta_{\infty}^{i}$ available for extrapolation.

EQUILIBRIUM ROCK TEMPERATURES IN GT-2

\section{Estimates of $\theta$ Between 1387 and $2040 \mathrm{~m}$}

Figure 5 shows $c^{i} \theta_{\infty}^{i}$ determinations of equilibrium rock temperature at specified depths between $1387 \mathrm{~m}(4550 \mathrm{ft})$ and $2040 \mathrm{~m}$ (6692 ft) in GT-2. Relaxation data are compiled in Appendix B. Table I gives regression coefficients and statistics for the 


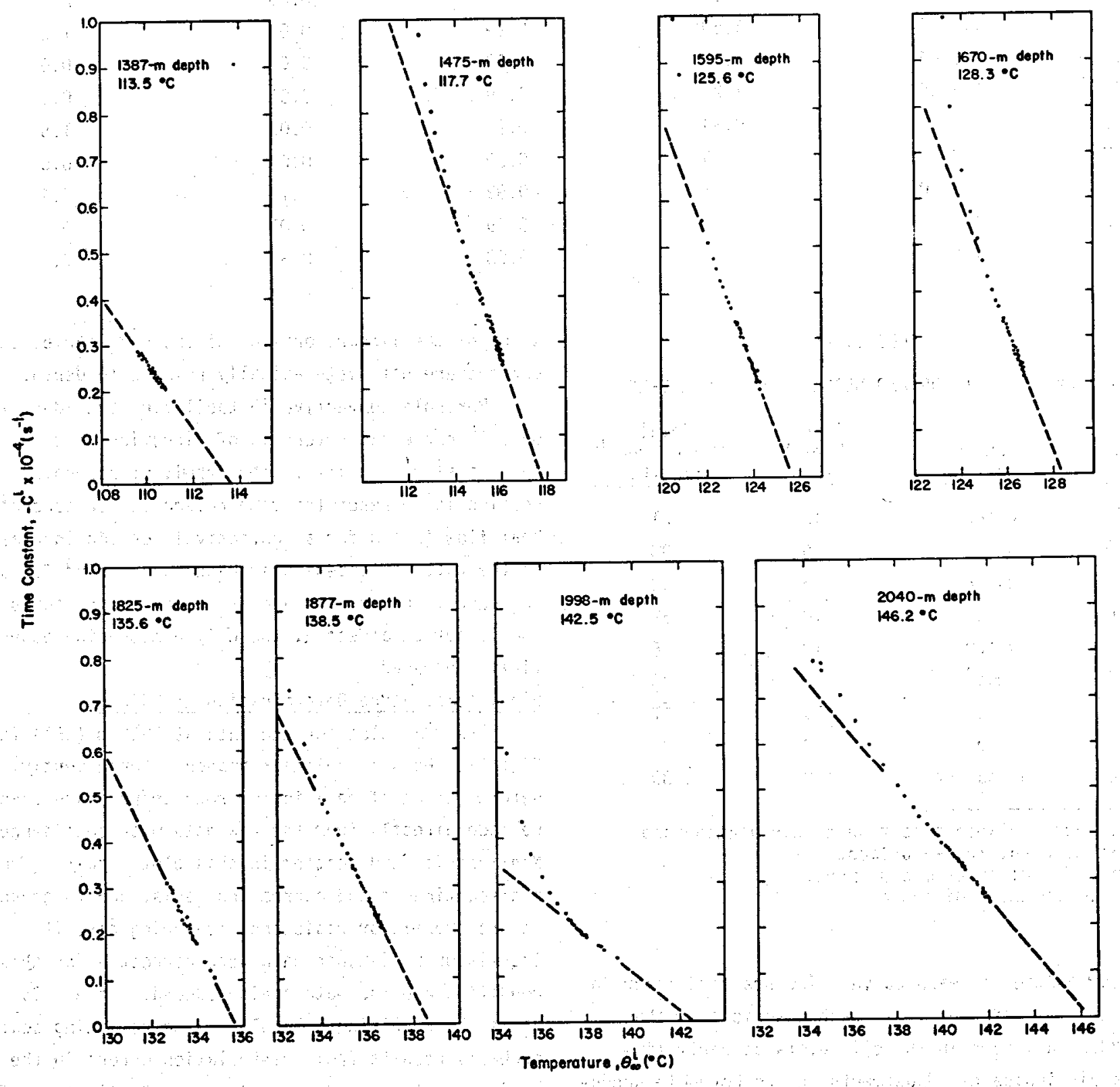

Fig. 5. Equilibrium rock determinations for various depths $\left(t^{i+1}-t^{i} \leq \frac{1}{2} h ; t_{2}^{i}-t_{0}^{i}=6 h\right)$. 
TABLE I

LINEAR REGRESSION PARAMETERS USED IN ESTIMATING $\theta_{\infty}$

\begin{tabular}{|c|c|c|c|c|c|}
\hline $\begin{array}{l}\text { Depth } \\
\text { (m) }\end{array}$ & $\begin{array}{c}\text { Equilibrium } \\
\text { Rock Temp } \theta_{\infty} \\
\left({ }^{\circ} \mathrm{C}\right) \\
\end{array}$ & $\begin{array}{r}-\frac{\Delta \theta_{\infty}^{i}}{\Delta c^{i}} \times 10^{4} \\
-\left({ }^{\circ} \mathrm{C}-\mathrm{sec}\right) \\
\end{array}$ & $\begin{array}{l}\text { Coefficient of } \\
\text { Determination }\end{array}$ & $\begin{array}{c}\text { Standard } \\
\text { Error in } \theta_{\infty} \\
\left({ }^{\circ} \mathrm{C}\right)\end{array}$ & $\begin{array}{l}\text { Standard Error } \\
\text { in } \frac{\Delta \theta^{i}}{\Delta c^{i}} \times 10^{3} \\
\left({ }^{\circ} \mathrm{C}-\mathrm{sec}\right)\end{array}$ \\
\hline 1387 & 113.58 & 13.35 & 0.99 & 0.06 & 2.3 \\
\hline 1475 & 117.78 & 6.50 & 0.99 & 0.04 & 1.2 \\
\hline 1595 & 125.66 & 7.15 & 0.99 & 0.02 & 0.6 \\
\hline 1670 & 128.35 & 7.29 & 0.99 & 0.01 & 0.5 \\
\hline 1825 & 135.63 & 9.34 & 0.99 & 0.03 & 1.5 \\
\hline 1877 & 138.57 & 9.29 & 0.99 & 0.04 & 0.5 \\
\hline 1998 & 142.50 & 24.47 & 0.99 & 0.10 & 5.4 \\
\hline 2040 & 146.20 & 16.06 & 0.99 & 0.01 & 0.5 \\
\hline 2900 & 195.84 & 3.35 & 0.98 & 0.22 & 7.7 \\
\hline
\end{tabular}

TABLE II

BOREHOLE CONDITIONS AND MEASUREMENT PARAMETERS

\begin{tabular}{|c|c|c|c|}
\hline $\begin{array}{c}\text { Depth } \\
\text { (m) }\end{array}$ & $\begin{array}{l}\text { Borehole } \\
\text { Condition }\end{array}$ & $\begin{array}{l}\text { Time } \\
\text { Lapse } \\
\text { (h) } \\
\end{array}$ & $\begin{array}{l}\text { Total } \\
\text { Measurement } \\
\text { Time (h) } \\
\end{array}$ \\
\hline 1387 & water & 12 & 21 \\
\hline 1475 & water & 6 & 30 \\
\hline 1595 & water & 6 & 48 \\
\hline 1670 & water & 10 & 32 \\
\hline 1825 & water & 19 & 36 \\
\hline 1877 & mud ' & 10 & 48 \\
\hline $1998^{C}$ & mud & 15 & 17 \\
\hline 2040 & mud & 2 & 20 \\
\hline 2900 & in adapter & 2 & 30 \\
\hline
\end{tabular}

${ }^{a}$ Time lapse between cessation of circulation and first temperature measurement.

$b_{\text {Hours of continuous measurement. }}$

$\mathrm{c}_{\text {Off bottom short distance. }}$

linear portion of each curve. The standard error in the determination of $\theta_{\infty}$ in each case is less than $0.1^{\circ} \mathrm{C}$. Curvature in the $c^{i} \theta^{i}$ plots at early time probably indicates adjustments in the borehole accenuated by the thermal inertia of the temperaturemeasuring system. Absence of strong curvature occurring in estimates at 1387 and $1825 \mathrm{~m}$ is primarily the result of a long lapse between the time circulation was stopped and the time the first temperature measurements were taken (Table II). Changes in the slope of the linear portions of the $c^{i} \theta_{\infty}^{i}$ curves occur but are not systematically related to depth.

Borehole convective instabilities are identified on $c^{i} \theta_{\infty}^{i}$ curves as reversals of direction of timesequential $c^{i} \theta_{\infty}^{i}$ points. The result of borehole convection is to reset the time reference for conductive heat flow (ahead for a convectively driven increase in the rate of temperature change and behind for a decrease). Hence, extrapolated rock temperatures should not be affected, the $c^{i} \theta_{\infty}^{i}$ plots being essentially retraced.

Final Temperature Determination at $2900 \mathrm{~m}$

The $c^{i} \theta_{\infty}^{i}$ plot for the data at $2900 \mathrm{~m}$ (9514 ft), Fig. 6a, shows a nonlinear branch. Consequently, a determination of equilibrium rock temperature cannot be made directly from the raw data with confidence. Nonlinearity and scatter in this plot resulted from a discontinuous and decreasing resistance to ground in the thermistor resistance-measuring circuit. The thermistor resistance data were corrected for this condition and the data again reduced. Figure $6 \mathrm{~b}$ shows the resulting $c^{i} \theta_{\infty}^{i}$ plot. The remaining scatter probably results from interpolation errors in the resistance-to-ground measurements. Application of regression analysis to data within limits of probable error (33 of 42 data points) gives a 0.98 goodnessof-fit and a bottomhole temperature determination of $195.8^{\circ} \mathrm{C}$.

Geothermal Gradient--Lower Precambrian Section

The geothermal gradient in the lower Precambrian section, 1387 to $2900 \mathrm{~m}$ (4550 to $9514 \mathrm{ft}$ ) is shown 


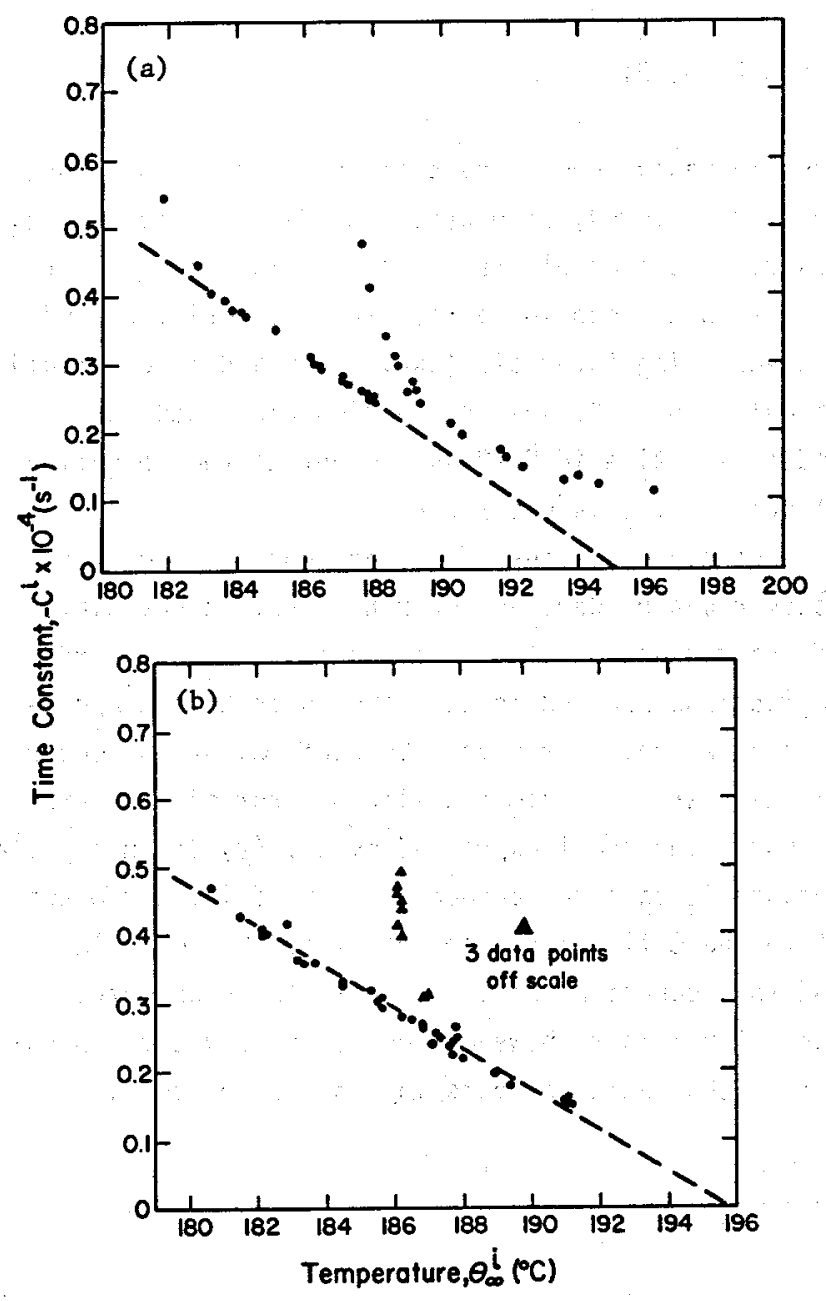

Fig. 6. Reduction of raw data from $2900 \mathrm{~m}$ (9514 ft) (top). Equilibrium rock determination using corrected relaxation data. Only circular data points were used in regression analysis (bottom).

in Fig. 7. The accuracy of each temperature determination is estimated to be $\pm 0.2^{\circ} \mathrm{C}$, with a corresponding precision of better than $0.1^{\circ} \mathrm{C}$ (except for the 2900-m, 9514-ft, point). The average gradient throughout the entire section is $54^{\circ} \mathrm{c} / \mathrm{km}$, increasing from $50^{\circ} \mathrm{C} / \mathrm{km}$ in the $1.2-$ to $2.1-\mathrm{km}$ (3940- to $6890-\mathrm{ft}$ ) interval to $60^{\circ} \mathrm{C} / \mathrm{km}$ in the $2.1-$ to $2.9-\mathrm{km}(6890-$ to 9514-ft) interval. Temperature logging subsequent to the completion of drilling indicates that the $50^{\circ} \mathrm{C} / \mathrm{km}$ gradient may extend to $2530 \mathrm{~m}(8300 \mathrm{ft})$, requiring a gradient greater than $60^{\circ} \mathrm{C} / \mathrm{km}$ from that depth to $2900 \mathrm{~m}(9514 \mathrm{ft})$.

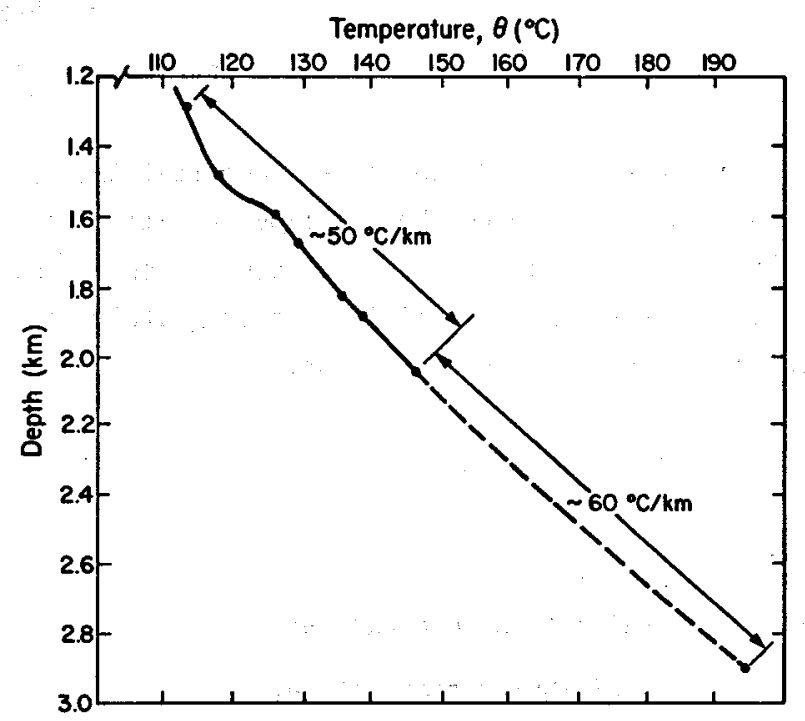

Fig. 7. Geothermal gradient in the lower Precambrian section of GT-2 $(1387-2900 \mathrm{~m}, 4550-9514 \mathrm{ft})$.

\section{REFERENCES}

1. A. H. Lachenbruch and M. C. Brewer, "Dissipation of the Temperature Effect in Drilling a Well in Arctic Alaska," USGS Bull. 1083-C, pp. 73-109 (1959).

2. L. R. Cooper and C. Jones, "The Determination of Virgin Strata Temperatures from Observations in Deep Boreholes," Geophy. J. 2, pp. 116-131 (1959).

3. J. C. Jaeger, "Application of the Theory of Heat Conduction to Geothermal Measurements," in Terrestrial Heat Flow, Geophys. Monograph 8, Edited by W. H. Lee, American Geophysical Union, Washington, D. C. (1965).

4. D. White, R. O. Fournier, L. J. P. Muffler, and A. H. Truesde11, "Physical Results of Research Driliing in Thermal Areas of Yellowstone Nat' 1 Park, Wyoming," USGS Prof. Paper 892 (at press).

5. T. W. Grisafi, H. H. Rieke, and D. R. Skidmore, "Approximation of Geothermal Gradients in Northern West Virginia Using Bottom-Hole Temperatures from Electric Logs," Am. Assoc. Petr. Geolog. Bu11. 58, pp. 321-323 (1974).

6. W. K. Summers, "Approximation of Thermal Gradients in Southeastern New Mexico Using BottomHole Temperatures from Electric Logs," Am. Assoc. Petr. Geolog. Bul1. 56, pp. 2072-2074 (1974).

7. M. Muskat, "Use of Data on the Buildup of BottomHole Pressures," Trans. AIME 123, pp. 44-48 (1937). 
Lachenbruch and Brewer have shown that the cooling of a well, in which the drilling operation approximates a constant linear heat source persisting throughout the time of drilling, is adequately described by an equation of the form

$$
\theta=\theta_{\infty}-\frac{q}{4 \pi K} f(t, s),
$$

where $f=\ln \frac{t}{t-s}$;

and $\theta$, relaxation temperature;

$\theta_{\infty}$, equilibrium temperature;

$t$, time elapsed since the drill bit reached the depth in question;

$q$, cooling per unit time per unit depth;

$K$, thermal conductivity of the rocks penetrated by the borehole;

$s$, time elapsed since the drill bit first reached the depth in question until the drilling operation ceased.
If only radial componenets of heat flow into a borehole are allowed, an expression identical to Eq. (2) describes bottomhole temperature relaxation. In this case $s$ is the cooling associated with drilling and post-drilling intervals (convection and forced fluid circulation). Because convection continued for an indefinite time in GT-2. subsequent to the cessation of drilling, $s$ is not known.

Likely estimates of $s$, and hence $\theta_{\infty}$ and $q / 2 \pi$, however can be derived through iterative calculations of the regression of $s$ on $f$ and its derivative $f^{\prime}$. Regressions applied to selected bottomhole temperature data from GT-2 give 0.99 coefficients of determination and $\theta_{\infty}$ estimates within error of the LASL method. The model expressed by Eq. (2) is incomplete because it does not account for the axial component of the heat flow into the bottom of the borehole, and thus cannot be used to verify the LASL method. Our calculations, however, do not preclude the possibility that axial effects may in fact be small. 
APPENDIX-B

TEMPERATURE RELAXATION DATA IN GT-2

TEMPERATURE MEASUREMENTS AT $1337 M$

\begin{tabular}{|c|c|c|c|}
\hline $\begin{array}{l}\text { TIME } \\
\text { (SEC) }\end{array}$ & $\begin{array}{l}\text { TEMP. } \\
(C C)\end{array}$ & $\begin{array}{l}\text { TIME } \\
\text { (SEC) }\end{array}$ & $\begin{array}{l}\text { TEMP } \\
(C)\end{array}$ \\
\hline-1 & $-\infty$ & --- & $-\infty$ \\
\hline & 104.055 & 27600 & 107.156 \\
\hline $\begin{array}{l}1200 \\
2400\end{array}$ & $\begin{array}{l}104.629 \\
104.428\end{array}$ & $\begin{array}{l}28900 \\
30000\end{array}$ & $\begin{array}{l}107.270 \\
107.330\end{array}$ \\
\hline 3600 & 104.604 & 31200 & 107.424 \\
\hline 4800 & 104.781 & 32400 & 107.505 \\
\hline 6000 & 104.947 & $\begin{array}{r}33600 \\
34900\end{array}$ & 107.586 \\
\hline 7200 & 105.108 & 34800 & 107.667 \\
\hline $\begin{array}{l}8400 \\
9600\end{array}$ & 105.263 & 36000 & $107 \cdot 742$ \\
\hline 10800 & $\begin{array}{l}105.413 \\
105.558\end{array}$ & 38400 & $\begin{array}{l}\text { 10 } \\
107.891\end{array}$ \\
\hline 12000 & 105.696 & 39600 & 107.960 \\
\hline 13200 & 10.5 .829 & 40800 & 108.028 \\
\hline 14400 & 105.963 & 42000 & 108.104 \\
\hline 15600 & 105.085 & 43200 & 108.166 \\
\hline 16800 & 106.213 & 44400 & 108.235 \\
\hline 18000 & 1.06 .330 & 45600 & 108.290 \\
\hline 19200 & 106.446 & 46800 & 108.353 \\
\hline 20400 & 106.557 & 48000 & 108.415 \\
\hline $\begin{array}{l}21600 \\
22800\end{array}$ & 106.661 & 49200 & $10 \theta .464$ \\
\hline 24000 & 106.871 & 51600 & $\begin{array}{l}108.55 \\
108.58\end{array}$ \\
\hline 2520 & 106.964 & 58800 & 108.6 \\
\hline 2640 & 107.053 & 54000 & 108.6 \\
\hline
\end{tabular}

TEMPERATURE MEASUREMENTS AT 1475M

\begin{tabular}{|c|c|c|c|}
\hline $\begin{array}{l}\text { TIME } \\
\text { (SEC) }\end{array}$ & $\begin{array}{l}\text { TEMP } \\
\text { CE }\end{array}$ & $\begin{array}{l}\text { TIME } \\
\text { (SEC) }\end{array}$ & $\begin{array}{l}\text { TEMP. } \\
\text { ('C) }\end{array}$ \\
\hline \\
\hline & 9.9444 2E 1 & 40800 & 113.185 \\
\hline 1200 & $9.96218 E_{1}$ & 42000 & 275 \\
\hline 2400 & 1. 0Е236E? & 43200 & 356 \\
\hline 3600 & 83E2 & 44400 & 457 \\
\hline 4800 & $1.04824 E 2$ & 45600 & 113.540 \\
\hline 6000 & $1.05665 \mathrm{EZ}$ & 46800 & 113.614 \\
\hline 7 & $5394 \mathrm{EZ}$ & 48000 & 699 \\
\hline 840 & $10 \mathrm{EZ}$ & 49200 & 73 \\
\hline 9 & $1.07572 E 2$ & 50400 & 40 \\
\hline 109 & 1 - 08097E2 & 51600 & 916 \\
\hline & 3548E2 & 52800 & 991 \\
\hline & 149E2 & 54000 & $0 \leq 7$ \\
\hline 1 & 1.3E2 & 55200 & 11 \\
\hline 15 & 45E2 & 56400 & 86 \\
\hline 16 & 1.09 & 57600 & 37 \\
\hline 18 & 1.10209E2 & 58800 & 88 \\
\hline 1 & $470 \mathrm{EZ}$ & 60 & 339 \\
\hline & $\begin{array}{l}02 E ? \\
14 E ?\end{array}$ & 61 & 50 \\
\hline & $\begin{array}{l}1.10914 \mathrm{EZ} \\
1.11112 \mathrm{E}\end{array}$ & 63500 & $\begin{array}{l}114.450 \\
114.493\end{array}$ \\
\hline & $1.11311 \mathrm{EZ}$ & 64800 & 114.544 \\
\hline 10 & $96 \mathrm{E2}$ & 66000 & 114.587 \\
\hline & 67E2 & 67200 & 114 \\
\hline & $31 \mathrm{EZ}$ & 68 & 11 \\
\hline & 8E2 & 69500 & 11 \\
\hline & $\begin{array}{l}39 E 2 \\
758 ?\end{array}$ & $\begin{array}{l}70800 \\
72000\end{array}$ & $\begin{array}{l}51 \\
94\end{array}$ \\
\hline & $73 E 2$ & 72000 & \\
\hline 0 & OSEE & 73200 & 329 \\
\hline & $\begin{array}{l}36 E 2 \\
57 E 2\end{array}$ & $\begin{array}{l}74400 \\
75600\end{array}$ & \\
\hline & $\begin{array}{l}\text { PEE } \\
8 E 2\end{array}$ & 76800 & 11 \\
\hline & 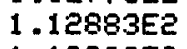 & & \\
\hline & & 79200 & 11 \\
\hline & & & \\
\hline
\end{tabular}


TEMPERATURE MEASIJREMENTS AT $1595 \mathrm{~m}$

\begin{tabular}{|c|c|c|c|}
\hline $\begin{array}{l}\text { TIME } \\
\text { SSECS }\end{array}$ & $\begin{array}{l}\text { TEMP. } \\
\text { CCS }\end{array}$ & $\begin{array}{l}\text { TIME } \\
\text { (SEC) }\end{array}$ & $\begin{array}{l}\text { TEMF } \\
\text { COS }\end{array}$ \\
\hline \\
\hline 0 & 112.489 & 70200 & 122.650 \\
\hline 1800 & 114.036 & 82000 & $12 e . r 05$ \\
\hline 3600 & 115.804 & 73800 & 122.785 \\
\hline 5400 & 116.427 & 75600 & 122.807 \\
\hline 7200 & $116.95 \mathrm{e}$ & 77400 & 122.856 \\
\hline 9000 & 117.411 & 79200 & 122.905 \\
\hline 10800 & 117.817 & 81000 & 122.950 \\
\hline 12600 & 118.180 & sesno & 122.999 \\
\hline 14400 & 118.514 & 84600 & 123 \\
\hline 16200 & 118.813 & 86400 & 123.084 \\
\hline 18000 & 119.088 & $89 e 00$ & 123.115 \\
\hline 19800 & 119.347 & 90000 & 123.156 \\
\hline 21600 & 119.580 & 91800 & 123.192 \\
\hline 23400 & 119.803 & 93600 & 123.228 \\
\hline 25200 & 120.003 & 95400 & 123.264 \\
\hline 27000 & 120.193 & 8200 & 123.309 \\
\hline 28800 & 120.372 & 99000 & 123.328 \\
\hline 30600 & 120.535 & 100800 & 123.360 \\
\hline 32400 & 120.692 & 102600 & 123.387 \\
\hline 34200 & 120.845 & 104400 & 123.419 \\
\hline 35000 & 120.982 & 106200 & .45 \\
\hline 37800 & 121.112 & 108000 & 10 \\
\hline 39600 & 121.238 & 109800 & 20 \\
\hline 41400 & 121.365 & 111600 & 12 \\
\hline 43200 & 121.470 & 113400 & 555 \\
\hline 45000 & 121.576 & 115200 & 123.574 \\
\hline 46800 & 121.674 & 117000 & 12 \\
\hline 48500 & 121.772 & 118800 & \\
\hline 50400 & 121.862 & $120 \leq 00$ & 13 \\
\hline 52200 & 121.953 & 122400 & 13 \\
\hline 54000 & $12 \mathrm{ez} 031$ & 124200 & \\
\hline 55800 & $12 \cos ^{113}$ & $1 \varepsilon \leqslant 000$ & .707 \\
\hline 57600 & 122.187 & 127800 & 12 \\
\hline 59400 & 122.261 & 129600 & 12 \\
\hline 61200 & 122.335 & 131400 & \\
\hline 63000 & 122.401 & 133200 & \\
\hline & $12 \mathrm{e} .467$ & 135000 & \\
\hline & 122.533 & 136900 & .817 \\
\hline 68400 & 122 & 0 & \\
\hline
\end{tabular}

TEMPERATURE MEASUREMENTS AT $1670 \mathrm{M}$

\begin{tabular}{|c|c|c|c|}
\hline TIME & TEMP. & TIME & TEMP. \\
\hline \\
\hline 0 & 115.598 & 45000 & 124.314 \\
\hline 1800 & 117.473 & 46800 & 124.413 \\
\hline 3600 & 118.556 & 48600 & 124.503 \\
\hline 5400 & 119.300 & 50400 & 124.597 \\
\hline 7200 & 119.871 & 52200 & 124.678 \\
\hline 9000 & 120.339 & 54000 & 124.763 \\
\hline 10800 & 120.746 & 55800 & 124.840 \\
\hline 12600 & 121.095 & 57600 & 124.916 \\
\hline 14400 & 121.415 & 59400 & 124.983 \\
\hline 16200 & 121.696 & 61200 & 125.051 \\
\hline 18000 & 121.958 & 63000 & 195.118 \\
\hline 19800 & 122.196 & 64800 & 125.181 \\
\hline 21600 & 122.419 & 66600 & 125.244 \\
\hline 23400 & $1 \mathrm{EE} . \mathrm{EZ1}$ & 68400 & $1 \geq 5.302$ \\
\hline 25200 & 122.812 & 70200 & 125.356 \\
\hline 27000 & 122.990 & 72000 & 125.409 \\
\hline 28800 & 123.156 & 73800 & 125.458 \\
\hline 30600 & 123.319 & 75600 & 125.507 \\
\hline 32400 & 123.469 & 77400 & 125.551 \\
\hline 34200 & 123.610 & 79200 & 125.595 \\
\hline 36000 & 123.743 & 81000 & 125.639 \\
\hline 37800 & 123.868 & 82800 & 125.663 \\
\hline & 123. & 84600 & 125.723 \\
\hline 41400 & 124.104 & 86400 & 125.762 \\
\hline 43000 & 124.211 & & 0.000 \\
\hline
\end{tabular}

TEMPERATURE MEASIUREMENTS AT 18ESM

\begin{tabular}{|c|c|c|c|}
\hline $\begin{array}{l}\text { TIME } \\
\text { (SEC) }\end{array}$ & $\begin{array}{l}\text { TEMP. } \\
(C)\end{array}$ & $\begin{array}{l}\text { TIME } \\
\text { (SEC) }\end{array}$ & $\begin{array}{l}\text { TEMP. } \\
\text { C } \mathrm{C})\end{array}$ \\
\hline \\
\hline 0 & :29.329 & 39600 & 131.83 \\
\hline 1800 & 129.519 & 41400 & 90 \\
\hline 3600 & 129.694 & 43200 & 131.968 \\
\hline 5400 & 129.864 & 45000 & 132.089 \\
\hline 7200 & 130.018 & 46000 & 132.090 \\
\hline 9000 & 130.173 & 48600 & 132.151 \\
\hline 10800 & 130.311 & 50400 & 132.207 \\
\hline 12600 & 130.444 & 52200 & 132.256 \\
\hline 14400 & 130.572 & 54000 & 132.312 \\
\hline 16200 & 130.689 & 55800 & 132.361 \\
\hline 18000 & 130.800 & 57600 & 132.405 \\
\hline 19800 & $130.90 \mathrm{~s}$ & 59400 & 132.448 \\
\hline 21600 & 131 & 61200 & 132.492 \\
\hline 23400 & 131.113 & 63000 & $132 \cdot 535$ \\
\hline 25200 & 131.208 & 64800 & 132.579 \\
\hline 27000 & 131.291 & 66600 & 132.616 \\
\hline 28800 & 131.381 & 68400 & 132.660 \\
\hline 30600 & 131.465 & 70200 & 132.704 \\
\hline & 131.543 & 72000 & 132.741 \\
\hline & SEl & 73800 & 132.779 \\
\hline 5 & $\begin{array}{l}131.694 \\
131.767\end{array}$ & 75600 & $132.81 ?$ \\
\hline & $6 r$ & & \\
\hline
\end{tabular}


TEMPERATURE MEASUREMENTS AT $1877 M$

\begin{tabular}{rlll} 
TIME & TEMP. & TIME & TEMP. \\
(SEC) & (C) & (SEC) & (C) \\
\hline 2 & & & \\
0 & 115.594 & 44800 & 133.107 \\
1800 & 121.704 & 46680 & 133.241 \\
3600 & 124.062 & 48480 & 133.392 \\
5400 & 125.404 & 50280 & 133.504 \\
7200 & 126.360 & 52080 & 133.626 \\
9000 & 127.121 & 53880 & 133.743 \\
10800 & 127.759 & 55680 & 133.847 \\
12600 & 128.303 & 57480 & 133.957 \\
14400 & 128.781 & 59280 & 134.049 \\
16200 & 129.223 & 61080 & 134.154 \\
18000 & 129.620 & 62880 & 134.240 \\
19800 & 129.984 & 64680 & 134.332 \\
21600 & 130.328 & 66480 & 134.418 \\
23400 & 130.630 & 68280 & 134.491 \\
25200 & 130.923 & 70080 & 134.578 \\
27000 & 131.190 & 71880 & 134.645 \\
28800 & 131.435 & 73680 & 134.719 \\
30600 & 131.670 & 75480 & 134.793 \\
32400 & 131.888 & 77280 & 134.860 \\
34200 & 132.102 & 79080 & 134.921 \\
35880 & 132.280 & 80880 & 134.981 \\
37680 & 132.466 & 82680 & 135.035 \\
39480 & 132.641 & 84480 & 135.096 \\
41280 & 132.804 & 86280 & 135.158 \\
43080 & 132.955 & 88080 & 135.205
\end{tabular}

TEMPERATURE MEASUREMENTS AT 1998M

\begin{tabular}{|c|c|c|c|}
\hline $\begin{array}{l}\text { TIME } \\
\text { (SEC) }\end{array}$ & $\begin{array}{l}\text { TEMP. } \\
\text { CES }\end{array}$ & $\begin{array}{l}\text { TIME } \\
\text { CSEC) }\end{array}$ & $\begin{array}{l}\text { TEMF } \\
\text { COS }\end{array}$ \\
\hline \multicolumn{4}{|r|}{$17-7: 7$} \\
\hline 0 & 130.479 & 25200 & 133.717 \\
\hline 1200 & 130.929 & 26400 & 133.814 \\
\hline 2400 & 131.220 & 27600 & 133.905 \\
\hline 3600 & 131.447 & 28800 & 133.997 \\
\hline 4800 & 131.646 & 30000 & 134.082 \\
\hline 6000 & 131.815 & 31200 & 167 \\
\hline 7200 & 131.974 & 32400 & 40 \\
\hline 8400 & 132.127 & 33600 & 326 \\
\hline 9600 & 132.269 & 34900 & 134.405 \\
\hline 10800 & 132.405 & 36000 & 134.485 \\
\hline 12000 & 132.529 & 37200 & 135.233 \\
\hline 13200 & 132.654 & 38400 & 632 \\
\hline $14400 \%$ & 132.773 & 39600 & 12 \\
\hline 15600 & 132.692 & 40800 & .786 \\
\hline 16800 & 133.006 & 42000 & 134.853 \\
\hline 18000 & 133.114 & 43200 & 134.927 \\
\hline 19200 & 133.222 & 44400 & 134.995 \\
\hline & 330 & 45600 & 663 \\
\hline & 133.427 & 46800 & 131 \\
\hline & 133.529 & 48000 & 135.199 \\
\hline & & & \\
\hline
\end{tabular}

TEMFERATURE MEASUREMENTS AT 2896M

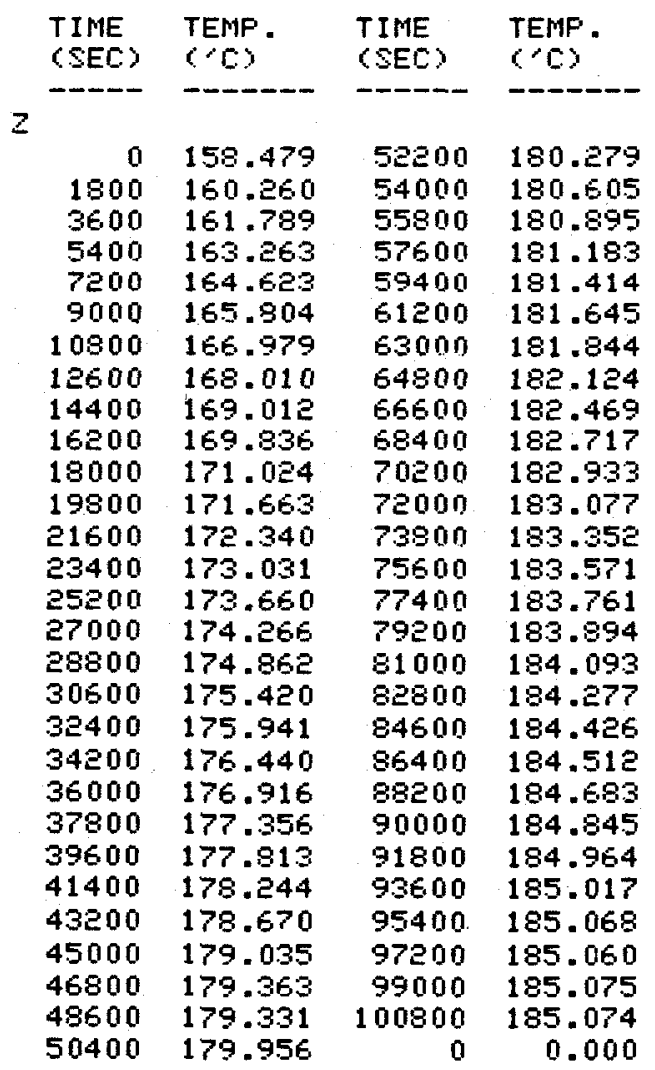

